Research Article

\title{
Analysis of the Accuracy of an FDR Sensor in Soil Moisture Measurement under Laboratory and Field Conditions
}

\author{
Anzhen Qin (i), Dongfeng Ning $\mathbb{B}^{\mathbb{B}}$, Zhandong Liu $(\mathbb{D}$, and Aiwang Duan \\ Key Laboratory of Crop Water Use and Regulation, Ministry of Agriculture and Rural Affairs, Institute of Farmland Irrigation, \\ Chinese Academy of Agricultural Sciences, Xinxiang, China 453002
}

Correspondence should be addressed to Dongfeng Ning; ningdongfeng@caas.cn and Zhandong Liu; liuzhandong@caas.cn

Received 11 November 2020; Revised 11 March 2021; Accepted 3 April 2021; Published 23 April 2021

Academic Editor: Jingwei Wang

Copyright (C) 2021 Anzhen Qin et al. This is an open access article distributed under the Creative Commons Attribution License, which permits unrestricted use, distribution, and reproduction in any medium, provided the original work is properly cited.

\begin{abstract}
Soil water content (SWC, \% vol) is a key factor affecting plant growth and development. SWC measurement is vital to rational use of water resources for irrigation, and the accuracy of sensors in SWC measurement is of significant importance to smart data-driven irrigation. Here, a laboratory experiment and a field lysimetric experiment were conducted to evaluate the accuracy of Insentek sensors under various soil conditions ( 1.1 to 1.5 bulk densities and sand to clay soil textures) and irrigation levels ( 30,45 , and $60 \mathrm{~mm}$ ), in 2018 and 2019. A microweighing lysimeter and oven-drying method were used as standard methods to compare the Insentek method. The root mean square error (RMSE, \% vol) and relative prediction deviation (RPD) between the Insentek and microlysimetric SWC values were $0.89-1.04 \%$ vol and 5.6-6.8, respectively, under laboratory condition. The RPD value is larger than the threshold value of 4.0, indicating the accuracy of the Insentek sensors is reliable under laboratory condition. Except for $60 \mathrm{~mm}$ irrigation treatment, the RMSE between Insentek and the oven-drying method under field condition was 1.44-1.93\% vol, and the RPD value was 1.56-1.93, lower than the threshold value of 4.0. The tiny gap between the Insentek sensor and soil may accelerate water infiltration along the probe $0-3 \mathrm{~d}$ after irrigation while increase air filling 5-7 d after irrigation, causing greater RMSE and lower RPD values. The dissatisfied performance in field condition may also be associated with the obvious drawbacks of oven-drying method, such as disturbance in soil sampling. When using oven-drying method to analyze the accuracy of the Insentek sensors in field condition, the concerns should be well addressed.
\end{abstract}

\section{Introduction}

Global demands for cereal grains are projected to increase by $50 \%$ by 2050 . To produce more food, agriculture has become the largest water consumer accounting for more than $60 \%$ of water withdrawn from resources worldwide [1]. With the ever-increasing demands for food and water, modern agriculture should be developed toward the precision agriculture with efficient use of water and nutrient resources [2]. Nevertheless, the present efficiency of irrigation is low. In China, the mean utilization coefficient of irrigation water was 0.45 in 2019 [3]. Precision irrigation according to soil moisture dynamics is the key to achieving high water use efficiency (WUE, $\mathrm{kg} \mathrm{m}^{-3}$ ). However, the main difficulty for precision irrigation lies in real-time and rapid monitoring of soil water content (SWC, \% vol) [4]. Over the past decades, scientists and engineers have developed various sensors to monitor the dynamics of soil moisture, including capacitive sensors (e.g., time-domain reflectometers (TDR) [5] and frequency domain reflectometers (FDR) [6]), neutron probes [7], and tensiometers [8]. TDR is a less-disturbing methodology, but the price of TDR sensor is relatively high [9]. As for neutron probes, it is difficult for the sensors to separate the signal of soil moisture from roots, giving rise to higher SWC estimates in upper soil layer [7], whereas tensiometers do not perform well in dry soil environment [8].

The Insentek sensor (Zhejiang Oriental Insentek Technology Ltd., Co, Hangzhou, China) is an FDR-type sensor that can automatically monitor SWC data. The sensor is based on the difference of relative dielectric permittivity (DP) in soils [4]. In general, DP of saturated soil at $20^{\circ} \mathrm{C}$ is 80 , while the DP of dry soil is 2-5 [10-12]. Through detecting the DP of soil, SWC can be determined. Compared with TDR sensors, the Insentek sensor has the advantages of rapid 


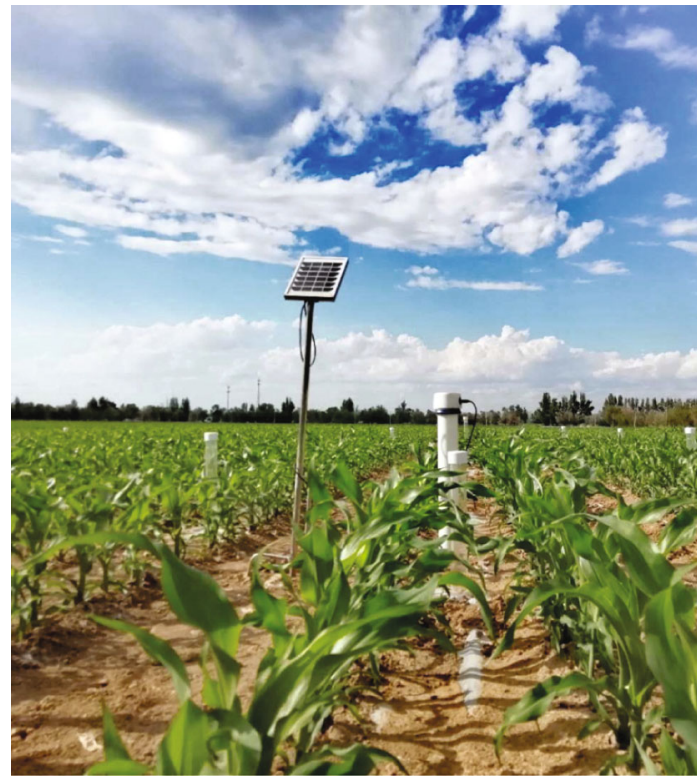

(a)

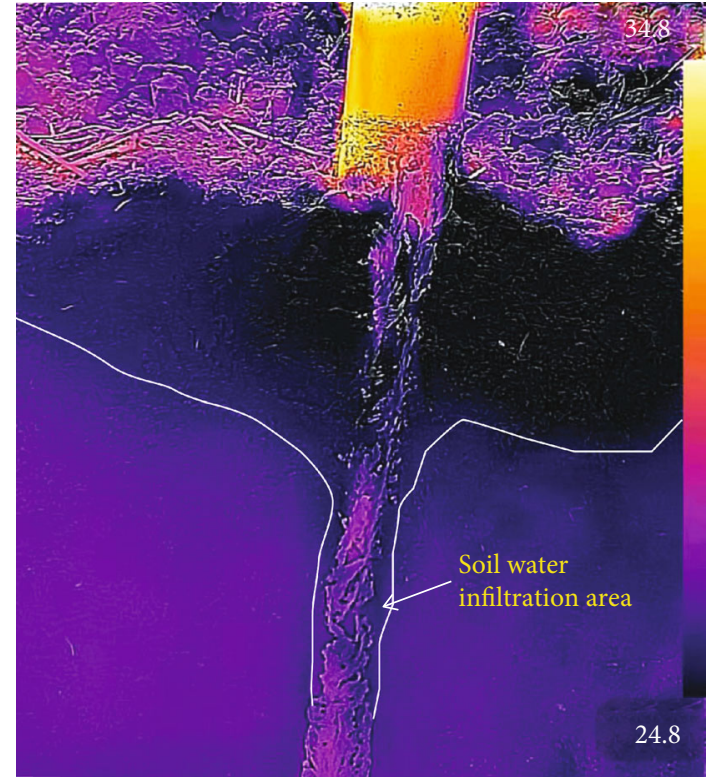

(b)

FIgURE 1: (a) Insentek sensor installed in maize plots at the Qitai experimental station in 2018. (b) Thermal image (24.8-34.8 $\left.{ }^{\circ} \mathrm{C}\right)$ of soil water infiltration area along an Insentek sensor in a lysimeter experiment $2 \mathrm{hr}$ after a $10 \mathrm{~mm}$ irrigation at Xinxiang experiment station, in June 2018.

speed of measurement, easy access to data, and low price in market [6]. The sensor is powered by a built-in lithiumpolymer rechargeable battery charged by a solar panel (see Figure 1(a)). Also, a built-in GPS module with wireless communication function allows the traceability of collected data [13]. Users are able to check the real-time SWC data using their PC or cellphones. This provides convenience for users without frequent visits to experimental sites [14]. So far, the latest figure has shown that there have been more than 35,000 Insentek sensors already installed across China, forming a nationwide soil moisture monitoring network across the country. When the sensors' year-round data were checked, they showed good continuity and stability [4]. However, in practice, we did find that there was an extremely tiny gap between the probe and soil, especially when the soil was dry. The gap allows the infiltration of water immediately after irrigation or heavy precipitation, which may overestimate SWC (see Figure 1(b)). However, when soils become drier, the gap will be filled with air, causing underestimates of SWC values since the DP of air is very low [15]. The problem of the gap exists in every tube-based SWC measurement methods, and it may inevitably cause errors in data.

In addition, the measurement accuracy of FDR sensors can be affected by soil temperature $[16,17]$. A temperaturedependent nonlinear model needs to be developed to compensate for the effects of temperature [18, 19]. Generally, the DP of soils decreases with increasing soil temperature, resulting in lower SWC estimates under higher temperature [20]. To minimize the negative effects, a temperature sensor and a moisture sensor were simultaneously installed in Insentek sensors. Engineers of Insentek sensors have performed thousands of experiments under various temperature and moisture levels in order to improve the accuracy of the sensors. Nevertheless, in published literature, the Insentek sensor studied in the present study has been characterized only once before [4]. In their published paper, the authors found that the Insentek sensor was an efficient tool in estimating maize evapotranspiration in the North China Plain with acceptable accuracy. However, the degree to which SWC values from Insentek sensors represent these of ovendrying method has not been well tested under both laboratory and field conditions.

In this study, the accuracy of Insentek sensors was tested both in laboratory and field conditions. We filled the gap with diluted mud in the installation of the sensors trying to exclude its adverse influences on SWC measurement. To start the experiment, a microlysimeter system was designed to test the sensors in laboratory, while in the field, a standard oven-drying method was adopted to evaluate the data of Insentek sensors. The experiment may help us validate the accuracy and reliability of Insentek sensors and better understand the uncertainty and variability in actual measurement. We hypothesized that Insentek sensors were able to monitor real-time SWC accurately both in laboratory and field conditions. The objectives of this study are (i) to validate the accuracy of Insentek sensors using microweighing lysimeters in laboratory condition and oven-drying method in field condition and (ii) to find out what factors may contribute to the variability in data if any.

\section{Materials and Methods}

2.1. Site Description. The experiment was carried out in June to August 2018 and 2019, at the Xinxiang experimental station of the Institute of Farmland Irrigation, Chinese Academy of Agricultural Sciences (CAAS) $\left(35^{\circ} 19^{\prime} \mathrm{N}, 113^{\circ} 53^{\prime} \mathrm{E}, 73.2 \mathrm{~m}\right.$ a.s.l.). The place has a continent temperate monsoon climate. Long-term (2009-2019) annual mean temperature is $14.1^{\circ} \mathrm{C}$, 


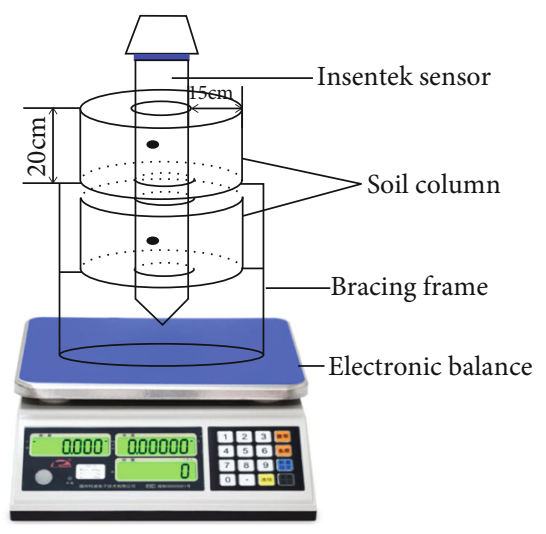

(a)

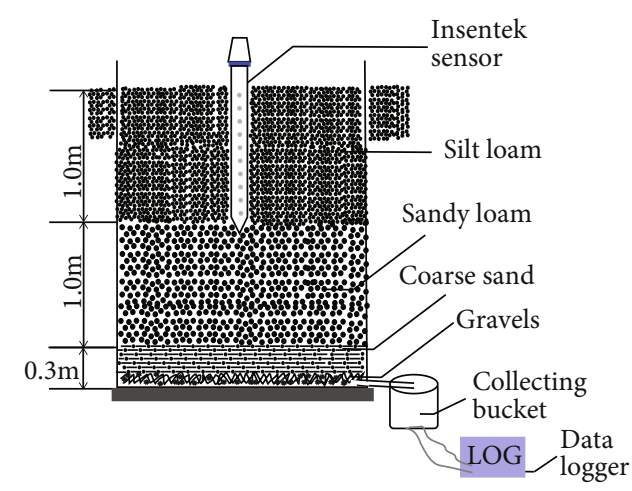

(b)

Figure 2: Schematic diagram of (a) a microweighing lysimetric system and (b) a nonweighing lysimeter system.

TABLE 1: Soil particle size distribution for soils sampled at different locations, in April and May 2018.

\begin{tabular}{|c|c|c|c|c|c|c|c|}
\hline Locations & Longitude & Latitude & Altitude & $\begin{array}{c}\text { Sand } \\
(>0.05 \mathrm{~mm})\end{array}$ & $\begin{array}{c}\text { Silt } \\
(0.002-0.05 \mathrm{~mm})\end{array}$ & $\begin{array}{c}\text { Clay } \\
(<0.002 \mathrm{~mm})\end{array}$ & Soil texture \\
\hline Huixian county & $35^{\circ} 30^{\prime}$ & $113^{\circ} 41^{\prime}$ & $94 \mathrm{~m}$ & $95.2 \%$ & $4.8 \%$ & 0 & Sand \\
\hline Yuanyang county & $34^{\circ} 59^{\prime}$ & $114^{\circ} 03^{\prime}$ & $86 \mathrm{~m}$ & $53.4 \%$ & $41.2 \%$ & $5.4 \%$ & Silt sand \\
\hline Yanjin county & $35^{\circ} 14^{\prime}$ & $114^{\circ} 15^{\prime}$ & $69 \mathrm{~m}$ & $45.7 \%$ & $28.6 \%$ & $25.7 \%$ & Sandy loam \\
\hline Muye district & $35^{\circ} 20^{\prime}$ & $113^{\circ} 46^{\prime}$ & $73 \mathrm{~m}$ & $41.1 \%$ & $34.8 \%$ & $24.1 \%$ & Silt loam \\
\hline Hongqi district & $35^{\circ} 07^{\prime}$ & $114^{\circ} 10^{\prime}$ & $71 \mathrm{~m}$ & $37.3 \%$ & $35.9 \%$ & $26.8 \%$ & Silt loam \\
\hline Changyuan county & $35^{\circ} 10^{\prime}$ & $114^{\circ} 41^{\prime}$ & $62 \mathrm{~m}$ & $17.7 \%$ & $43.8 \%$ & $38.5 \%$ & Loam clay \\
\hline Qinyang county & $35^{\circ} 04^{\prime}$ & $112^{\circ} 55^{\prime}$ & $126 \mathrm{~m}$ & $8.8 \%$ & $35.1 \%$ & $56.1 \%$ & Clay \\
\hline
\end{tabular}

annual precipitation $582 \mathrm{~mm}$, annual sunshine hour $2497 \mathrm{hr}$, and frost-free period $220 \mathrm{~d}$. The soil is a silt loam soil [21]. Field holding capacity and permanent wilting point in $0-$ $100 \mathrm{~cm}$ soil layers was $24 \%$ and $9 \%$ (by weight), average bulk density across the $0-100 \mathrm{~cm}$ soil depth was $1.42 \mathrm{~g} \mathrm{~cm}^{-3}$, and water table was detected more than $5 \mathrm{~m}$ below the soil surface. Soil available $\mathrm{N}, \mathrm{P}$, and $\mathrm{K}$ contents were $72,17.8$, and $100 \mathrm{mg} \mathrm{kg}^{-1}$, respectively. Soil organic carbon content was $6.54 \mathrm{~g} \mathrm{~kg}^{-1}$, and soil $\mathrm{pH}$ was around 7.5.

2.2. Experimental Design. The experiment consisted of a microweighing lysimeter experiment in the Key Laboratory of Crop Water Use and Regulation, CAAS, from June 1st to August 30th, 2018 (see Figure 2(a)), and a nonweighing lysimeter experiment under an automatic rainproof shelter at the Xinxiang experimental station from June 1st to August 30th, 2019 (see Figure 2(b)). In the microlysimeter experiment, three microlysimetric systems were designed to evaluate the accuracy of Insentek sensors across various soil bulk densities from 1.1 to $1.5 \mathrm{~g} \mathrm{~cm}^{-3}$ and soil textures from sand to clay. Soils with different textures were sampled at various locations during April and May 2018 (see Table 1). When soils were collected, all stones and root debris were removed by riddling. The soils were then repacked carefully into a transparent acrylic (PMMA) tube. Different soil bulk densities were achieved by manually compacting. The Insentek sensor was installed vertically through the central circle of the soil column.

Soils collected at different locations in 2018 were classified according to their soil particle size distribution. Sand and silt sand were integrated as a sand soil, since its sand particle content was larger than $50 \%$ and clay content less than $10 \%$. Similarly, sandy loam and silt loam were integrated as a loam soil, since its sand content was $25-50 \%$, and silt content $25-40 \%$; loam clay and clay were integrated as a clay soil, with its clay content larger than $35 \%$ and silt content larger than $30 \%$ [21]. The microweighing lysimetric system consisted of an electronic weighing balance, an Insentek sensor, and two soil columns. The precision of the balance was $\pm 10^{-4} \mathrm{~g}$. Since the maximum measuring radius of an Insentek sensor was $15 \mathrm{~cm}$ in soils, and the diameter of the sensor was $6.5 \mathrm{~cm}$, the total diameter of the soil column was designed $36.5 \mathrm{~cm}$ and the height $20 \mathrm{~cm}$, which was considered to fully cover the measuring range of the sensor. Each type of tested soil was packed in a transparent acrylic (PMMA) tube. The junction between the sensor and the PMMA tube was sealed with glue to prevent water drainage. During the measuring period, soils were first added distilled water to holding capacity and then were air dried to wilting point under natural environment. The measurements were performed in laboratory condition at a constant temperature of $26 \pm 0.5^{\circ} \mathrm{C}$. After soils were mixed with water, soil columns were placed for a 
period of $12 \mathrm{hr}$ to obtain a uniform moisture distribution. The weight changes of soils were automatically recorded by the microweighing lysimeters. In the meantime, SWC (\% vol) was monitored by Insentek sensor. The battery of the Insentek sensor was fully charged in advance. The charged battery can power the sensor to work as long as two months without recharging.

In large-scale lysimeter experiment, it consisted of nine lysimeters $(3.3 \mathrm{~m}$ long $\times 2.0 \mathrm{~m}$ wide $\times 2.3 \mathrm{~m}$ deep $)$ packed uniformly with silt loam soil in the $0-100 \mathrm{~cm}$ soil layers and sandy loam soil in the $100-200 \mathrm{~cm}$ soil layers. The bottom $30 \mathrm{~cm}$ was filled with coarse sands and $<3 \mathrm{~cm}$ gravels to permit drainage toward lysimeter outlet. Collecting buckets were placed at the bottom side of lysimeters to hold gravity drainage effluent. These lysimeters were arranged in two rows. Between the rows, a $2.5 \mathrm{~m}$ wide concrete platform was constructed level with the top of the lysimeters. Nine Insentek sensors were installed at the center of each lysimeter to compare SWC measured by the standard oven-drying method. Electrically operated rainproof shelters were installed for the lysimeters. The shelters were moved over all lysimeters before precipitation happened. Three irrigation levels were arranged in a complete random design, including $30 \mathrm{~mm}$, $45 \mathrm{~mm}$, and $60 \mathrm{~mm}$ per irrigation, respectively. Each plot was irrigated separately, and different amounts of water were applied using surface irrigation, and a precision flow meter (Shanghai Water Meter Manufacturing Ltd., Co, Shanghai, China) was installed to measure and control the irrigation amounts. Preirrigation SWC was measured both by Insentek sensor and oven-drying method. After irrigation, SWC was continuously monitored by Insentek sensors at $2 \mathrm{hr}$ interval. Due to the labor cost of soil-core sampling, SWC was measured by an oven-drying method at $2 \mathrm{hr}$ interval for the first $8 \mathrm{hr}$ after irrigation, at $4 \mathrm{hr}$ interval for the next $24 \mathrm{hr}$, and $6 \mathrm{hr}$ interval for the remaining days. The measurement usually lasted $7 \mathrm{~d}$ and repeated for three times.

2.3. Soil Water Content and Infiltration Measurements. $100 \mathrm{~cm}$ long Insentek sensors were used to monitor SWC (\% vol) at $10 \mathrm{~cm}$ increment to a depth of $100 \mathrm{~cm}$ in field condition. $40 \mathrm{~cm}$ long Insentek sensors were adopted to monitor SWC at $20 \mathrm{~cm}$ and $40 \mathrm{~cm}$ depth in soil columns in laboratory condition. The sensors measured SWC every $10 \mathrm{~min}$, and the average of two hours was stored in dataloggers and was transmitted to a local server via the $4 \mathrm{G}$ wireless network.

Microlysimeters were designed to measure the weight changes of soil column every two hours, and the data were stored in dataloggers. We used the average of a whole day to calculate daily changes of soil column weight. SWC on the $i$ th day was derived from initial SWC and the difference in SWC $(\triangle \mathrm{SWC})$ using Equation (1):

$$
S W C_{i}=S W C_{i n i}-\sum_{i=1} \Delta S W C
$$

where $S W C_{i}$ is soil water content (\% vol) on the $i$ th day, $S$ $W C_{i n i}$ is the initial SWC at the beginning of the experiment, and $\triangle S W C$ is the daily difference between SWC on the previous and the current measurement date.
In this study, $\triangle \mathrm{SWC}$ is derived from the changes of soil column weight $(\Delta \mathrm{Wt}, \mathrm{g})$ using Equation (2):

$$
\Delta S W C=\frac{\Delta W t}{H \cdot \pi \cdot\left(R^{2}-r^{2}\right) \cdot \rho},
$$

where $\triangle S W C$ is the daily difference in SWC (\% vol), $\Delta W t$ the daily change in soil column weight (g), $H$ is the height of soil column $(\mathrm{cm}), R$ and $r$ are the radius $(\mathrm{cm})$ of the soil column and of the Insentek sensor, and $\rho$ is the density of water $\left(\mathrm{g} \mathrm{cm}^{-3}\right)$.

Soil gravimetric water content $(\% w / w)$ was measured at $10 \mathrm{~cm}$ increment to a depth of $100 \mathrm{~cm}$ using a soil auger $(3 \mathrm{~cm}$ in diameter). Soil cores were randomly sampled about 20$30 \mathrm{~cm}$ away from Insentek sensor, then were oven-dried at $105^{\circ} \mathrm{C}$ for $8 \mathrm{hr}$ after the fresh weight weighed. SWC was measured on a dry weight basis. Soil bulk density $\left(\mathrm{g} \mathrm{cm}^{-3}\right)$ at the same depth and interval was determined before and after the experiment using stainless steel ring method [22]. SWC (\% vol) was calculated by multiplying soil gravimetric water content with soil bulk density $\left(\mathrm{g} \mathrm{cm}^{-3}\right)$ from the same layer.

In this study, infiltration area was defined as a product of infiltration depth $(\mathrm{cm})$ and duration of infiltration after irrigation (d), which indicated how deep and how long irrigation amount affected SWC. The unit of infiltration area is $\mathrm{cm} \mathrm{d}$. Infiltration area was derived from pixel area estimated using the software Image (NIH, Maryland, USA). Since the maximum infiltration depth was $50 \mathrm{~cm}$ in the present study, the area was calculated within $0-50 \mathrm{~cm}$ soil depth using Equation (3):

$$
S_{\text {in }}=S_{\max } \frac{S_{p i}}{S_{\max -p i}},
$$

where $S_{\text {in }}$ is infiltration area $(\mathrm{cm} \mathrm{d}), S_{\max }$ is the maximum infiltration area $(350 \mathrm{~cm} \mathrm{~d})$, which is a product of maximum infiltration depth $(50 \mathrm{~cm})$ and maximum duration after irrigation (7d), $S_{p i}$ is pixel area, and $S_{\max -p i}$ is the total pixel area.

2.4. Goodness-of-Fit Test. The evaluation factors include slope and coefficient of determination $\left(R^{2}\right)$ for linear regression between the microlysimetric and Insentek data, and between the oven-drying and Insentek data. The slope of a line characterizes the direction of a line. The ideal slope is 1.0, indicating SWC data by the Insentek sensor are equal to those of microlysimeter or oven-drying method. The $R^{2}$ describes the proportion of variance in SWC data using microlysimeter or oven-drying method explained by the Insentek data. In addition, the root mean square error (RMSE) and relative prediction deviation (RPD) were adopted to evaluate the accuracy of Insentek sensors. The RMSE was used to investigate the differences between the microlysimeter and Insentek data, and the between oven-drying and Insentek data. The RMSE was calculated using Equation (4):

$$
R M S E=\sqrt{\sum_{i=1}^{n}\left(x_{i n s e n}-x_{j}\right)^{2} / n},
$$




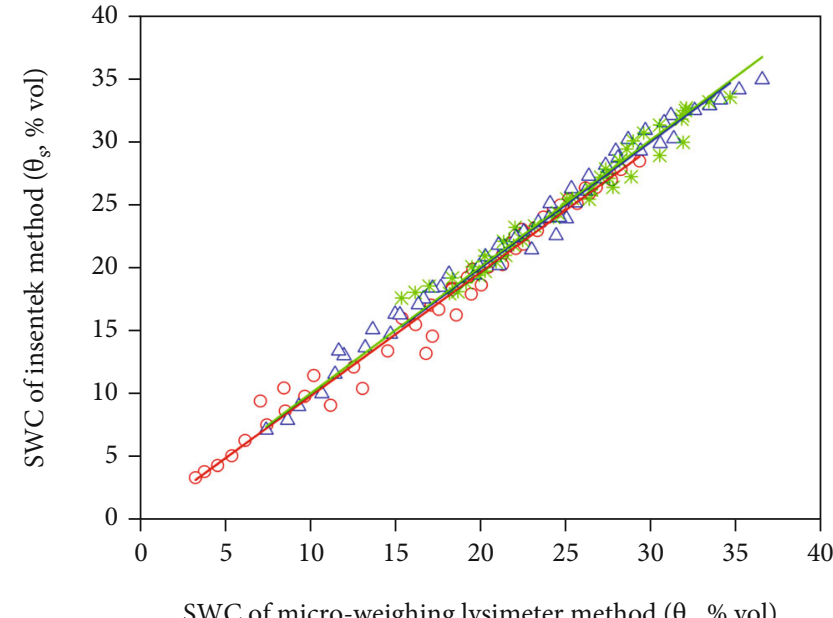

SWC of micro-weighing lysimeter method $\left(\theta_{\mathrm{s}}, \% \mathrm{vol}\right)$

$$
\begin{aligned}
& \triangle \text { Sand } \\
& \begin{array}{l}
\triangle \text { Loam } \\
\text { * Clay }
\end{array} \quad-\quad y=0.986 \times R^{2}=0.997 \\
& \quad-y=1.008 \times R^{2}=0.995 \\
&
\end{aligned}
$$

(a)

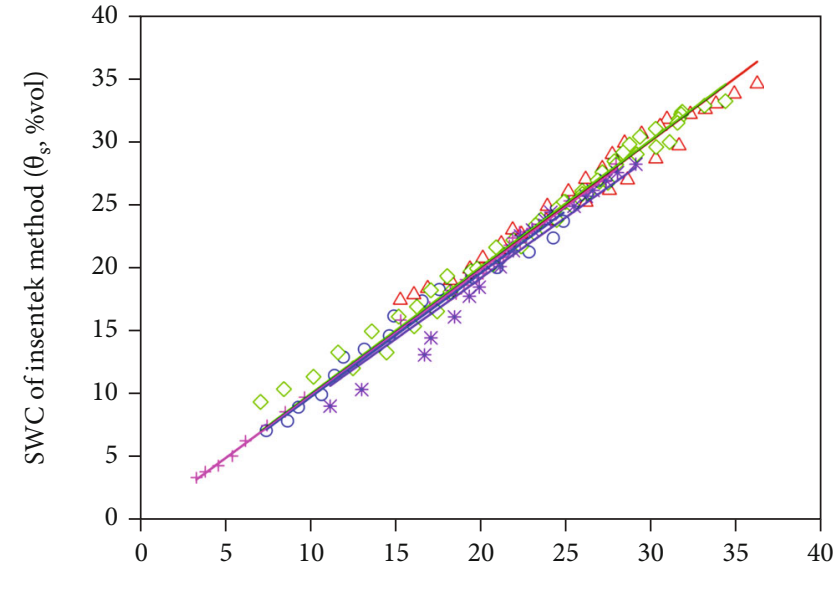

SWC of micro-weighing lysimeter method $\left(\theta_{\mathrm{s}}, \% \mathrm{vol}\right)$

$$
\begin{aligned}
& \circ 1.1-y=0.985 x R^{2}=0.997 \\
& \triangle 1.2-y=1.007 x R^{2}=0.998 \\
& \diamond 1.3 \\
& +1.4 \\
& \text { * } 1.5 \\
& \text { - } y=1.009 \times R^{2}=0.999 \\
& \text { - } y=0.999 \times R^{2}=1.000 \\
& \text { — } y=0.965 \times R^{2}=0.996
\end{aligned}
$$

\begin{tabular}{|c|c|c|c|c|c|c|c|c|}
\hline \multirow{2}{*}{ Treatments } & & \multicolumn{3}{|c|}{ Microweighing lysimetric values (\% vol) } & \multicolumn{2}{|c|}{ Goodness-of-fit } & \multirow{2}{*}{$R^{2}$} & \multirow[b]{2}{*}{$p$} \\
\hline & & WP & FC & Average SWC & RMSE & RPD & & \\
\hline \multirow{3}{*}{ Soil texture } & Sand & $3.46 \mathrm{c}$ & $28.6 \mathrm{~b}$ & $18.09 \mathrm{c}$ & 1.044 & 6.78 & 0.997 & 0.0001 \\
\hline & Loam & $7.26 \mathrm{~b}$ & $35.1 \mathrm{a}$ & $22.71 \mathrm{~b}$ & 0.927 & 7.99 & 0.995 & 0.0001 \\
\hline & Clay & $17.7 \mathrm{a}$ & $33.7 \mathrm{a}$ & $25.35 \mathrm{a}$ & 0.897 & 5.61 & 0.997 & 0.0001 \\
\hline \multirow{5}{*}{ Soil bulk density $\left(\mathrm{g} \mathrm{cm}^{-3}\right)$} & 1.1 & $7.47 \mathrm{~b}$ & $25.1 \mathrm{c}$ & $15.6 \mathrm{c}$ & 0.921 & 5.93 & 0.997 & 0.0001 \\
\hline & 1.2 & $17.7 \mathrm{a}$ & $35.1 \mathrm{a}$ & $26.4 \mathrm{a}$ & 1.164 & 4.68 & 0.998 & 0.0001 \\
\hline & 1.3 & $7.14 \mathrm{~b}$ & $33.7 \mathrm{a}$ & $23.8 \mathrm{~b}$ & 0.863 & 7.88 & 0.999 & 0.0001 \\
\hline & 1.4 & $3.46 c$ & $28.8 \mathrm{~b}$ & $17.9 \mathrm{c}$ & 0.320 & 22.8 & 1.000 & 0.0001 \\
\hline & 1.5 & $9.22 \mathrm{~b}$ & $28.2 \mathrm{~b}$ & $21.1 \mathrm{~b}$ & 1.482 & 3.71 & 0.996 & 0.0001 \\
\hline
\end{tabular}

(b)

FIGURE 3: Linear correlation between soil water content (\% vol) measured using the Insentek and microweighing lysimetric methods across (a) different soil textures (sand, loam, and clay) and (b) soil bulk densities (1.1 to $1.5 \mathrm{~g} \mathrm{~cm}^{-3}$ ).

TABLE 2: Goodness-of-fit test between soil water content (SWC, \% vol) calculated based on Insentek sensor and oven-drying method across different soil textures and soil bulk densities.

Note: WP is wilt point; FC is field holding capacity; $R^{2}$ is coefficient of determination; RMSE is root mean square error; RPD is relative prediction deviation, and values measured by Insentek sensor are reliable with $\mathrm{RPD} \geq 4.0$; and $p$ is probability. Different letters in each column indicate significant differences at $p<0.05$.

where RMSE is root mean square error, $x_{\text {Insen }}$ and $x_{j}$ are corresponding SWC values estimated by the Insentek and microlysimetric or oven-drying method, respectively, and $n$ is the number of values evaluated. The smaller the RMSE values are, the more accurate the Insentek sensor is.

RPD is used to indicate the reliability of Insentek data. RPD was calculated using Equation (5):

$$
R P D=S T D E V\left(x_{j}\right) / R M S E,
$$

where $R P D$ is relative prediction deviation and $\operatorname{STDEV}\left(x_{j}\right)$ is standard deviation of microlysimetric or oven-drying SWC values. $R P D \geq 4.0$ indicates Insentek data are reliable; $1.4<$ $R P D<4.0$ means the data are feasible but needs to be improved; $R P D \leq 1.4$ indicates the data are unreliable [4].

2.5. Statistical Analysis. Data were analyzed using an analysis of variance with the Statistical Analysis Software (version 19.0, SPSS Inc., Chicago, IL, USA). Significance was declared at the probability level of 0.05 , unless otherwise stated. Relationships among SWC by the Insentek, microlysimeter, and oven-drying methods were analyzed by means of the Levenberg-Marquardt Algorithm. Figures were plotted using Original Pro 9.1 (Origin Lab Corporation, Northampton, MA, USA). 


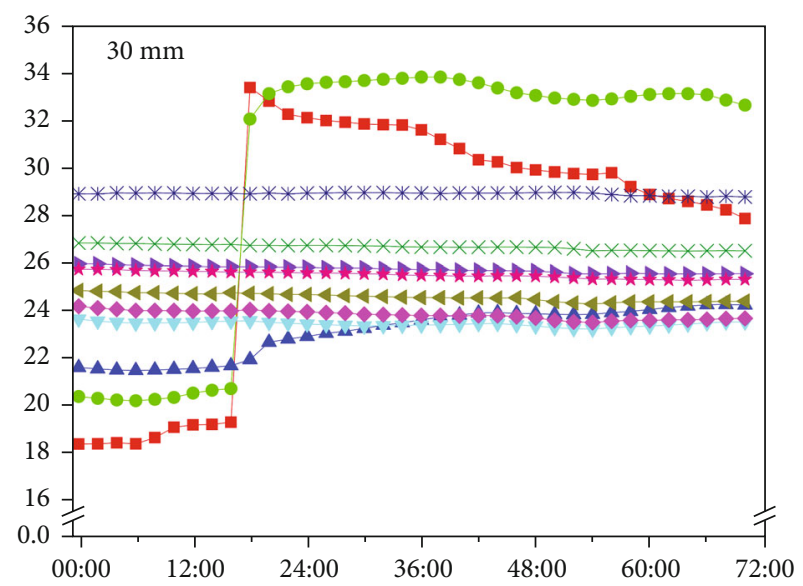

(a)

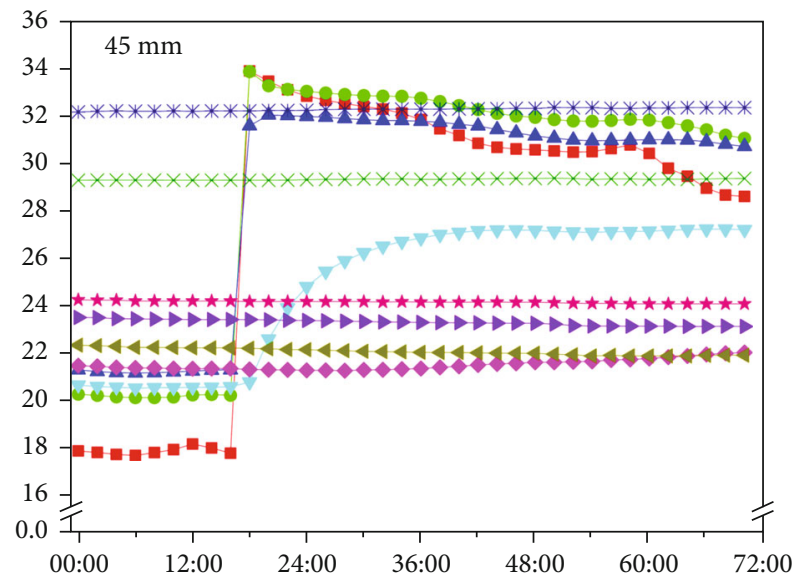

(b)

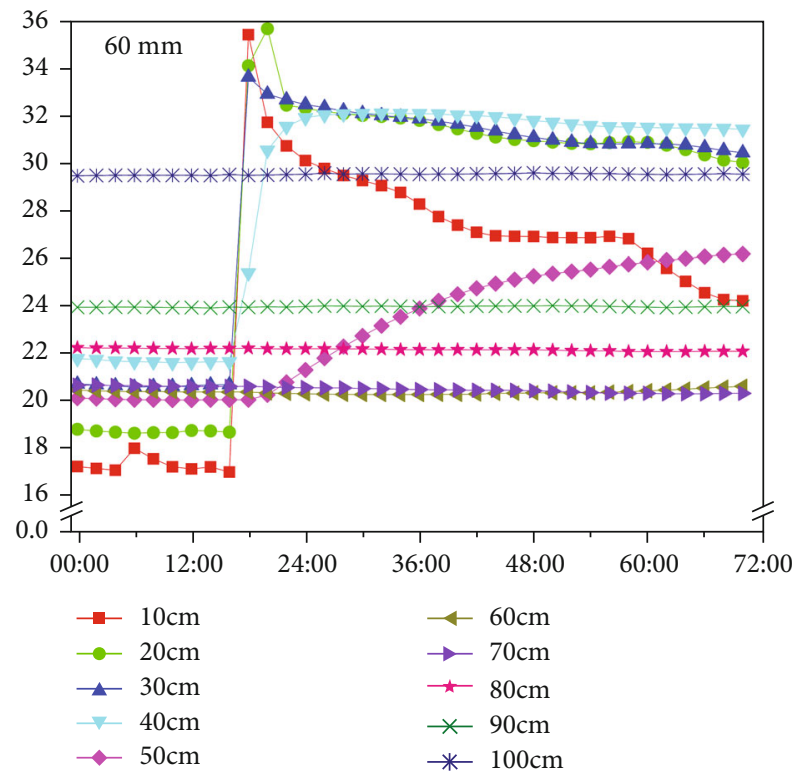

(c)

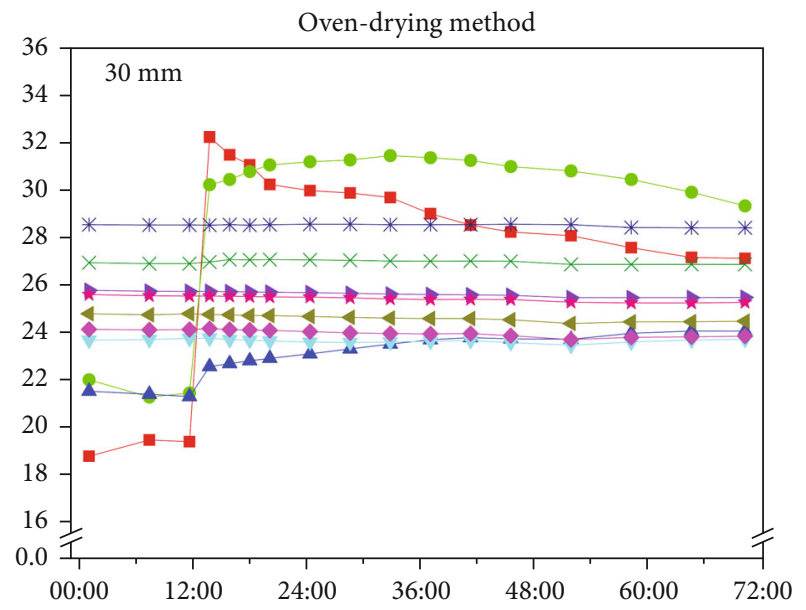

(d)

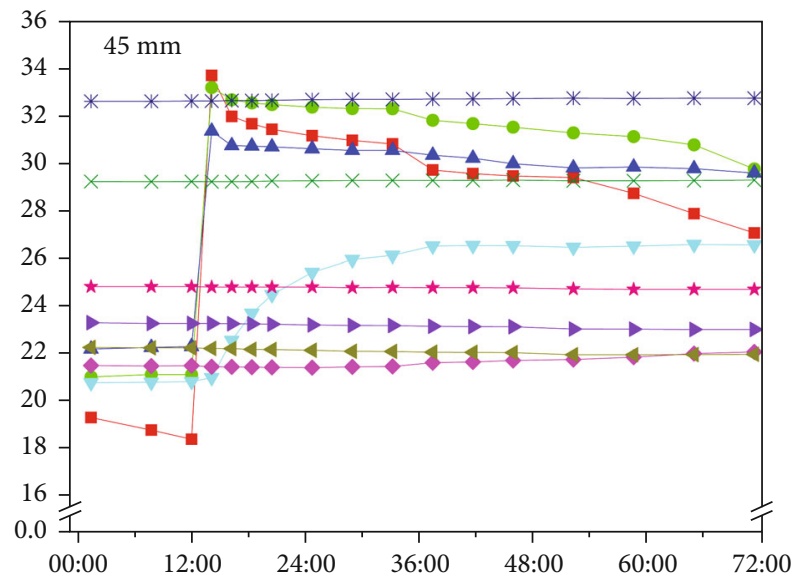

(e)

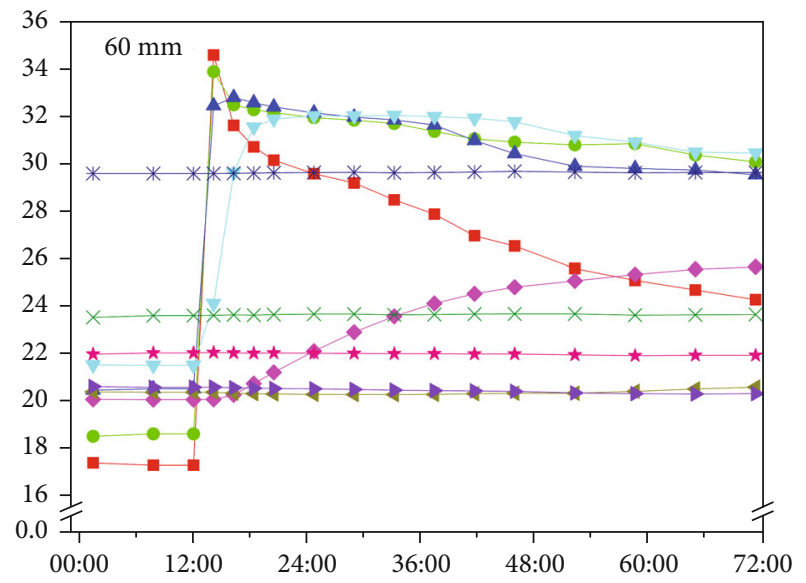

(f)

Figure 4: Dynamics of soil volumetric water content (\% vol) for each $10 \mathrm{~cm}$ soil layer to a depth of $0-100 \mathrm{~cm}$ measured using the Insentek and oven-drying methods before and after irrigation events applied at the amounts of $30 \mathrm{~mm}(\mathrm{a}, \mathrm{d}), 45 \mathrm{~mm}(\mathrm{~b}, \mathrm{e})$, and $60 \mathrm{~mm}$ (c, f), respectively. 


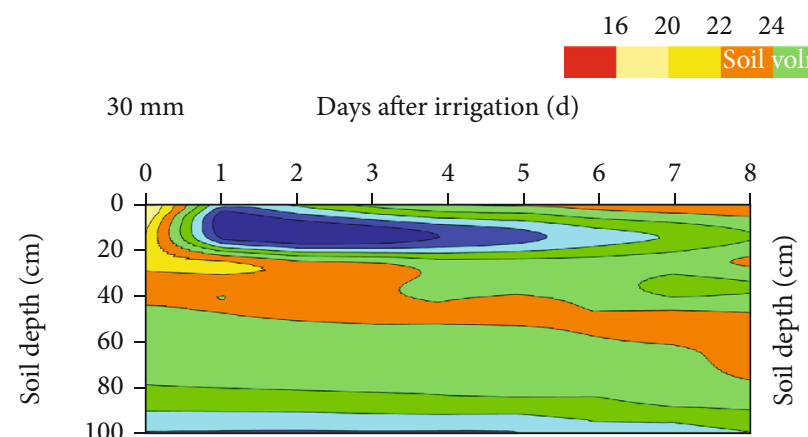

(a)

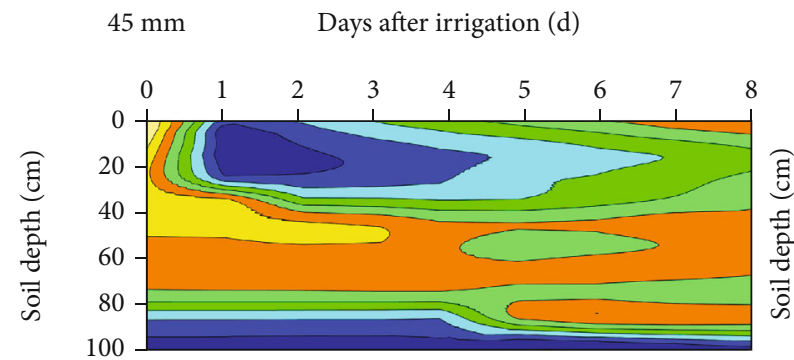

(b)

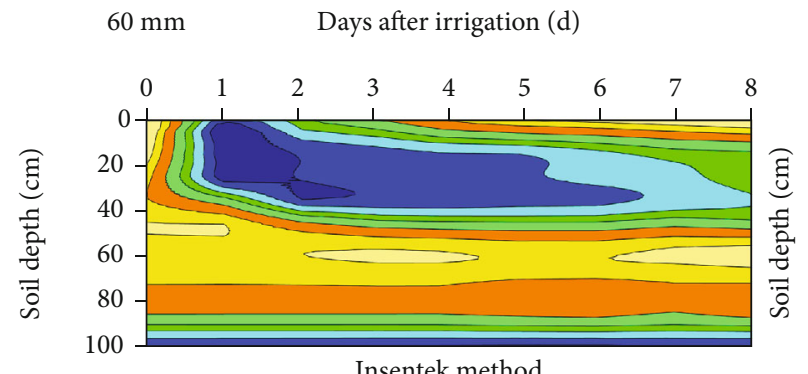

(c)

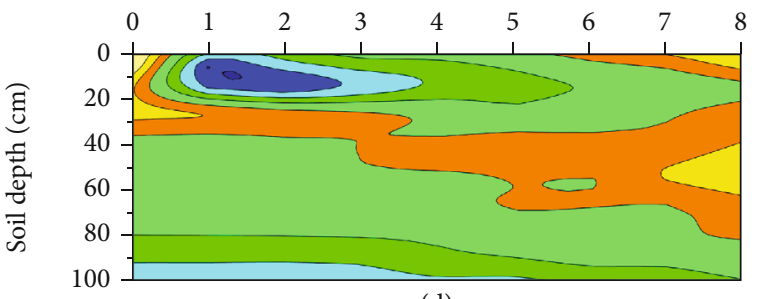

(d)

$45 \mathrm{~mm} \quad$ Days after irrigation (d)

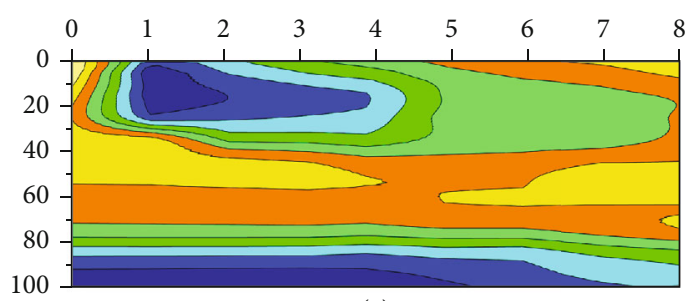

(e)

$60 \mathrm{~mm} \quad$ Days after irrigation (d)

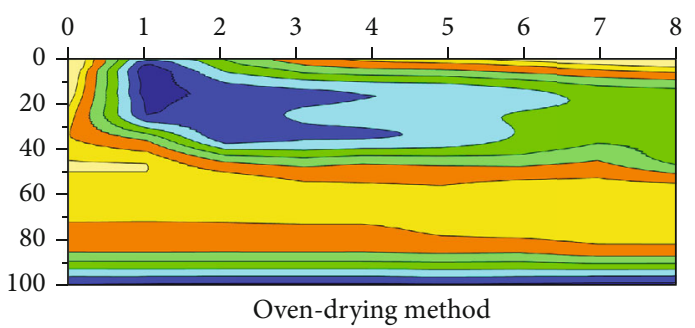

(f)

Figure 5: Contour plot of soil volumetric water content (\% vol) in 0-100 cm soil layer measured using the Insentek and oven-drying methods before and after different irrigation events applied at the amounts of $30 \mathrm{~mm}(\mathrm{a}, \mathrm{d}), 45 \mathrm{~mm}(\mathrm{~b}, \mathrm{e})$, and $60 \mathrm{~mm}(\mathrm{c}, \mathrm{f})$, respectively.

\section{Results and Discussion}

3.1. Comparison of Soil Water Content between Insentek and Microlysimetric Methods. SWC measured by Insentek sensor had a significant positive linear correlation with the data calculated by microlysimetric system (see Figure 3). Coefficient of determination $\left(R^{2}\right)$ of the linear functions for sand, loam, and clay soils was between 0.995 and 0.997 , and that for different soil bulk densities $\left(1.1-1.5 \mathrm{~g} \mathrm{~cm}^{-3}\right)$ was between 0.996 and 1.000. The correlation between microlysimetric and Insentek data was extremely significant $(p<0.001)$. The soil physical property test showed that the wilting point of sandy and loam soil was significantly lower than that of clay, while the field holding capacity of loam and clay soil was higher than that of sandy soil (see Table 2). Consequently, the available SWC of loam soil is significantly greater than that of sandy and clay soils. According to the goodness-of-fit test, the RMSE between Insentek and microlysimetric SWC values is between 0.89 and $1.04 \% \mathrm{vol}$, and the RPD is between 5.6 and 6.8 , larger than the threshold value (4.0), which indicates that the accuracy of Insentek sensor is high in laboratory condition. The best range of bulk density for the
Insentek sensor in SWC measurement is $1.1-1.4 \mathrm{~g} \mathrm{~cm}^{-3}$. Under high bulk density of $1.5 \mathrm{~g} \mathrm{~cm}^{-3}$, the RMSE remains $1.48 \%$ vol, and RPD is 3.7, less than the threshold value.

So far, the standard oven-drying method is considered the most accurate method of SWC measurement [22]. Similarly, the weighing lysimetric method is regarded the most reliable approach to estimate crop evapotranspiration [6]. However, the oven-drying method is destructive, laborious, and time-consuming. That promotes the development of nondestructive, low-cost technique for SWC measurement. The Insentek sensor is an inexpensive and easy-to-use FDR probe, compared with TDR sensors. Before being applied to precision irrigation, Insentek sensors should be proven accurate and reliable in SWC measurement under a variety of field conditions. In laboratory condition, Insentek sensors have better performance in clay and loam soils compared to sandy soils, which is consistent with the results of Adla et al. [23]. The reason may be related to more reasonable range of available SWC for loam soils than sandy soils.

\subsection{Comparison of Soil Water Content and Infiltration} between Insentek and Oven-Drying Methods. SWC prior to 
TABLE 3: Infiltration area $(\mathrm{cm} \mathrm{d})$ within the $0-50 \mathrm{~cm}$ soil depth converted using pixel area.

\begin{tabular}{|c|c|c|c|c|c|c|c|}
\hline Treatments & $\begin{array}{c}\text { Irrigation } \\
\text { quota }(\mathrm{mm})\end{array}$ & $\begin{array}{c}\text { Range of } \\
\text { SWC (\% vol) }\end{array}$ & $\begin{array}{l}\text { Pixel area within } \\
0-50 \mathrm{~cm} \text { depth }\end{array}$ & $\begin{array}{l}\text { Percent of total } \\
\text { pixel area (\%) }\end{array}$ & $\begin{array}{l}\text { Infiltration } \\
\text { depth }(\mathrm{cm})\end{array}$ & $\begin{array}{l}\text { Duration after } \\
\text { irrigation }(\mathrm{d})\end{array}$ & $\begin{array}{c}\text { Infiltration area } \\
\text { within } 0-50 \mathrm{~cm} \\
\text { depth }(\mathrm{cm} \mathrm{d})\end{array}$ \\
\hline Maximum value & & $0-36$ & 10 & 100 & 50 & 7.0 & 350 \\
\hline \multirow{9}{*}{ Insentek method } & \multirow{3}{*}{30} & $32-36$ & 0.68 & 6.8 & 18 & 4.3 & 24 \\
\hline & & $28-32$ & 1.63 & 16.3 & 21 & 5.8 & 57 \\
\hline & & $24-28$ & 4.61 & 46.1 & 43 & 7.0 & 161 \\
\hline & \multirow{3}{*}{45} & $32-36$ & 0.65 & 6.5 & 31 & 1.7 & 23 \\
\hline & & $28-32$ & 3.31 & 33.1 & 38 & 5.8 & 116 \\
\hline & & $24-28$ & 3.69 & 36.9 & 48 & 7.0 & 129 \\
\hline & \multirow{3}{*}{60} & $32-36$ & 0.71 & 7.1 & 36 & 1.8 & 25 \\
\hline & & $28-32$ & 4.47 & 44.7 & 42 & 7.0 & 156 \\
\hline & & $24-28$ & 2.06 & 20.6 & 50 & 7.0 & 72 \\
\hline \multirow{9}{*}{ Oven-drying method } & \multirow{3}{*}{30} & $32-36$ & 0.019 & 1.9 & 12 & 0.4 & 6.7 \\
\hline & & $28-32$ & 1.04 & 10.4 & 19 & 2.7 & 36 \\
\hline & & $24-28$ & 4.28 & 42.8 & 39 & 7.0 & 150 \\
\hline & \multirow{3}{*}{45} & $32-36$ & 0.41 & 4.1 & 25 & 1.1 & 14 \\
\hline & & $28-32$ & 2.05 & 20.5 & 33 & 3.3 & 72 \\
\hline & & $24-28$ & 4.17 & 41.7 & 45 & 6.9 & 146 \\
\hline & \multirow{3}{*}{60} & $32-36$ & 0.23 & 2.3 & 26 & 0.6 & 8 \\
\hline & & $28-32$ & 3.98 & 39.8 & 41 & 5.6 & 139 \\
\hline & & $24-28$ & 3.81 & 38.1 & 50 & 7.0 & 133 \\
\hline
\end{tabular}

Note: maximum infiltration depth is $50 \mathrm{~cm}$ under the three irrigation treatments. Pixel area is calculated using the software ImageJ (NIH, Maryland, USA). Infiltration area is the product of infiltration depth $(\mathrm{cm})$ and duration after irrigation (d).

TABLE 4: Goodness-of-fit test for soil water content (\% vol) between the Insentek and oven-drying methods.

\begin{tabular}{|c|c|c|c|c|c|c|c|c|}
\hline \multirow{2}{*}{ Treatments } & & \multirow{2}{*}{ Linear regression equation } & \multicolumn{2}{|c|}{ Average SWC (\% vol) } & \multicolumn{2}{|c|}{ Goodness-of-fit } & \multirow{2}{*}{$R^{2}$} & \multirow{2}{*}{$p$} \\
\hline & & & Insentek & Oven-drying & RMSE & RPD & & \\
\hline \multirow{3}{*}{ Irrigation amount $(\mathrm{mm})$} & 30 & $y=0.9623 x$ & 24.7 & 23.8 & 1.436 & 1.56 & 0.778 & 0.01 \\
\hline & 45 & $y=0.9671 x$ & 26.2 & 25.3 & 1.930 & 1.93 & 0.784 & 0.01 \\
\hline & 60 & $y=0.9819 x$ & 25.2 & 24.8 & 0.977 & 4.04 & 0.912 & 0.001 \\
\hline
\end{tabular}

Note: $y$ is soil water content (SWC, \% vol) of Insentek method; $x$ is SWC of oven-drying method; RMSE is root mean square error (\% vol); RPD is relative prediction deviation; $R^{2}$ is coefficient of determination; and $p$ is probability.

irrigation was similar between Insentek and oven-drying methods (see Figure 4). However, postirrigation SWC measured by Insentek sensors was larger than that of ovendrying method. Specifically, SWC in $0-10 \mathrm{~cm}$ soil layer decreased noticeably with time under $60 \mathrm{~mm}$ treatment. For $30 \mathrm{~mm}$ treatment, SWC in $10-20 \mathrm{~cm}$ layer remained stable within $1.0 \mathrm{~d}$ after irrigation and then gradually declined. As for SWC in $20-30 \mathrm{~cm}$ soil layer, it increased gradually and reached the maximum SWC values $2 \mathrm{~d}$ after irrigation under $30 \mathrm{~mm}$ treatment, while for SWC in $0-30 \mathrm{~cm}$ soil layer, it reached the maximum values within $1 \mathrm{~d}$ after irrigation under 45 and $60 \mathrm{~mm}$ treatments and remained stable for the remaining $6 \mathrm{~d}$. Under $45 \mathrm{~mm}$ and $60 \mathrm{~cm}$ treatments, the mean SWC in $30-50 \mathrm{~cm}$ soil layers increased gradually with time and eventually reached the maximum values $3.0 \mathrm{~d}$ after irrigation. Averaged across the three irrigation treatments, postirrigation SWC of 10-20 cm layer measured by Insentek sensors is $7.0 \%$ higher than that of oven-drying method
(33.3\% vs. $31.1 \%$ ). Similarly, SWC of $20-30 \mathrm{~cm}$ soil layer measured by Insentek sensors is $5.6 \%$ higher, and that of $30-50 \mathrm{~cm}$ layer is $4.8 \%$ higher $(p<0.05)$, respectively, than that of the oven-drying method. Irrigation treatments showed nonsignificant effect $(p<0.05)$ on SWC below $50 \mathrm{~cm}$ soil layer. Besides, SWC below $50 \mathrm{~cm}$ layer was similar between the Insentek and oven-drying methods.

Figure 5 shows the differences in infiltration area between the Insentek and oven-drying methods. The maximum infiltration depth was detected $50 \mathrm{~cm}$ under the three irrigation treatments. Although the infiltration depth measured by the two methods was generally the same, the duration of infiltration (d) after irrigation measured by the oven-drying method was much shorter than that of the Insentek method, especially for the $30 \mathrm{~mm}$ treatment. Under the $30 \mathrm{~mm}$ treatment, the duration of infiltration for SWC ranging from 32 to $36 \%$ vol was $4.3 \mathrm{~d}$ by the Insentek method, $3.9 \mathrm{~d}$ longer than that of the oven-drying method (see Table 3 ). 
In this study, the difference in infiltration area between the Insentek and oven-drying methods was larger in the upper $0-10 \mathrm{~cm}$ depth, but it became smaller with soil depth. The result was consistent with the findings of DomínguezNiño et al. [24]. In addition, other factors, such as soil temperature, were considered attributable to influence sensor accuracy [25]. Diurnal variations in soil temperature are heterogeneous across different soil depths [26] and are generally larger in the upper soil layer, resulting in disturbance in sensor measurement. To solve the problem, a temperature sensor and a moisture sensor have been installed in the Insentek sensors, and then, thousands of experiments were performed to develop proper temperature compensation models to improve the accuracy of the sensors [27]. In laboratory with a constant temperature, our results proved that soil texture and bulk density had little impact on the accuracy of Insentek sensors, except sandy soil with high bulk density. The result was consistent with Domsch et al. [28]. In general, sandy soil texture and high bulk density are associated with high thermal conductivity of soil [29], which negatively affects the soil dielectric constant [30], and thus SWC data.

3.3. Goodness-of-Fit Test between the Insentek and OvenDrying Methods. Slopes for equations between Insentek and oven-drying methods were $<1.0$, indicating SWC measured by the oven-drying method was constantly lower, which was probably due to the destruction of soils causing increases in soil evaporation in upper soils and thus leading to lower SWC (see Table 4). In soil sampling, great efforts were made to reduce destructive effects on soils, leaving soils within the measuring radius $(15 \mathrm{~cm})$ of the Insentek sensor unchanged. During the experiment, sampling locations were kept a distance of $20-30 \mathrm{~cm}$ away from the Insentek sensor. After soil sampling, holes were filled with original soils. However, some artificial factors such as compactness of soil and destruction of macro soil pores inevitably contributed to the variability of experimental results. We suggest that disturbance to the soils should be minimized when choosing the oven-drying method to calibrate SWC sensors. The overestimates of SWC and infiltration area may also be associated with the tiny gap between the tube and soil. It has been learned that the outer layer of the Insentek sensor was made of chlorinated polyvinyl chloride with high chlorinated polyethylene (HCPE) coating, which helped improve the corrosion resistance to soil chemicals. To eliminate the impact of the gap on SWC measurement, it is suggested to adopt proper chemical material that has the same thermal expansion coefficient as soils.

\section{Conclusions}

We performed a comparative study using microweighing lysimeter and oven-drying methods to assess the accuracy of Insentek sensors in SWC measurement under laboratory and field conditions. The results showed that, in laboratory condition, the SWC of Insentek sensors had a significant $(p<0.001)$ positive correlation to that of microweighing lysimeter across various soil textures and bulk densities, except sandy soil with high bulk density. In field condition, the Insentek method monitored the same infiltration depth as the oven-drying method did, but the duration of infiltration after irrigation was longer by the Insentek method. The accuracy of the Insentek sensor tested by the microlysimetric method in laboratory condition was higher than that of oven-drying method in field condition. The discrepancy in the SWC data between the Insentek and oven-drying methods was likely attributable to the tiny gap between the tube and soil. Also, the disturbance to soils in the ovendrying method may also contribute to variability in SWC data. Compared with the microlysimetric method, the oven-drying method with continuous disturbance in soil sampling may have drawbacks in assessing the accuracy of Insentek sensor in field conditions. We consider the microweighing lysimetric method an appropriate approach to assess the accuracy and reliability of the SWC measurement sensors.

\section{Data Availability}

The data used to support the findings of this study have not been made available because it is only available for researchers and collaborators of Key Laboratory of Crop Water Use and Regulation, CAAS.

\section{Conflicts of Interest}

The authors declare that they have no conflicts of interest.

\section{Acknowledgments}

This research was funded by the National Key Research and Development Program of China (2017YFD0301102), the Central Public Interest Scientific Institution Basal Research Fund (Farmland Irrigation Research Institute, CAAS, FIRI2020-02), the Agricultural Science and Technology Innovation Program (ASTIP) of Chinese Academy of Agricultural Sciences, the China Agriculture Research System (CARS-02), and the Scientific and Technological Project of Henan Province (212102110069).

\section{References}

[1] D. K. Ray, N. Ramankutty, N. D. Mueller, P. C. West, and J. A. Foley, "Recent patterns of crop yield growth and stagnation," Nature Communications, vol. 3, no. 1, 2012.

[2] P. Placidi, L. Gasperini, A. Grassi, M. Cecconi, and A. Scorzoni, "Characterization of low-cost capacitive soil moisture sensors for IoT networks," Sensors, vol. 20, no. 12, 2020.

[3] A. Guo, D. Jiang, F. Zhong et al., "Prediction of technological change under shared socioeconomic pathways and regional differences: a case study of irrigation water use efficiency changes in Chinese provinces," Sustainability, vol. 11, no. 24, 2019.

[4] A. Qin, D. Ning, Z. Liu et al., "Insentek sensor: an alternative to estimate daily crop evapotranspiration for maize plants," Water, vol. 11, no. 1, 2019.

[5] Y. Zhu, S. Irmak, A. Jhala, M. Vuran, and A. Diotto, “Timedomain and frequency-domain reflectometry type soil 
moisture sensor performance and soil temperature effects in fine- and coarse-textured soils," Applied Engineering in Agriculture, vol. 35, no. 2, pp. 117-134, 2019.

[6] A. Qin, D. Ning, Z. Liu et al., "Structural equation modeling of soil moisture effects on evapotranspiration of maize in the North China plain," National Academy Science Letters, vol. 43, no. 3, pp. 219-224, 2020.

[7] M. Duygu and Z. Akyürek, "Using cosmic-ray neutron probes in validating satellite soil moisture products and land surface models," Water, vol. 11, no. 7, 2019.

[8] R. Muñoz-Carpena, Y. Li, W. Klassen, and M. Dukes, "Field comparison of tensiometer and granular matrix sensor automatic drip irrigation on tomato," HortTechnology, vol. 15, no. 3, pp. 584-590, 2005.

[9] J. Oliveira, E. Pinto, V. Silva Neto, and A. D'Assunção, “CSRRbased microwave sensor for dielectric materials characterization applied to soil water content determination," Sensors, vol. 20, no. 1, 2020.

[10] K. Kupfer, E. Trinks, N. Wagner, and C. Hübner, "TDR measurements and simulations in high lossy bentonite materials," Measurement Science and Technology, vol. 18, no. 4, pp. 11181136, 2007.

[11] G. Topp, S. Zegelin, and I. White, "Impacts of the real and imaginary components of relative permittivity on time domain reflectometry measurements in soils," Soil Science Society of America Journal, vol. 64, no. 4, pp. 1244-1252, 2000.

[12] C. Gao, Y. Zhao, and Y. Zhao, "A novel sensor for noninvasive detection of in situ stem water content based on standing wave ratio," Journal of Sensors, vol. 2019, Article ID 3594964, 10 pages, 2019.

[13] S. Zang, K. Hou, and S. Nguang, "Underground communications using capacitive data transfer devices," Journal of Sensors, vol. 2020, Article ID 8849618, 11 pages, 2020.

[14] J. Jabro, W. Stevens, W. Iversen, B. Allen, and U. Sainju, "Irrigation scheduling based on wireless sensors output and soilwater characteristic curve in two soils," Sensors, vol. 20, no. 5, 2020.

[15] R. Aroca, A. Hernandes, D. Magalhães, M. Becker, C. Vaz, and A. Calbo, "Calibration of passive UHF RFID tags using neural networks to measure soil moisture," Journal of Sensors, vol. 2018, Article ID 3436503, 12 pages, 2018.

[16] M. Lu, J. Kapilaratne, and I. Kaihotsu, "A data-driven method to remove temperature effects in TDR-measured soil water content at a Mongolian site," Hydrological Research Letters, vol. 9, no. 1, pp. 8-13, 2015.

[17] E. Nagahage, I. Nagahage, and T. Fujino, "Calibration and validation of a low-cost capacitive moisture sensor to integrate the automated soil moisture monitoring system," Agriculture, vol. 9, no. 7, 2019.

[18] L. Lin, Y. He, Z. Xiao, K. Zhao, T. Dong, and P. Nie, "Rapiddetection sensor for rice grain moisture based on NIR spectroscopy," Applied Sciences, vol. 9, no. 8, 2019.

[19] J. Kapilaratne and M. Lu, "Automated general temperature correction method for dielectric soil moisture sensors," Journal of Hydrology, vol. 551, pp. 203-216, 2017.

[20] D. Xiao, J. Feng, N. Wang, X. Luo, and Y. Hu, "Integrated soil moisture and water depth sensor for paddy fields," Computers and Electronics in Agriculture, vol. 98, pp. 214-221, 2013.

[21] National Standards of China (NSC), "China Soil Classification and Code (GB/T 17296-2009)," NSC, Beijing, China, 2009.
[22] A. Qin, Y. Fang, D. Ning et al., "Incorporation of manure into ridge and furrow planting system boosts yields of maize by optimizing soil moisture and improving photosynthesis," Agronomy, vol. 9, no. 12, 2019.

[23] S. Adla, N. Rai, S. Karumanchi, S. Tripathi, M. Disse, and S. Pande, "Laboratory calibration and performance evaluation of low-cost capacitive and very low-cost resistive soil moisture sensors," Sensors, vol. 20, no. 2, 2020.

[24] J. Domínguez-Niño, J. Oliver-Manera, G. Arbat, J. Girona, and J. Casadesús, "Analysis of the variability in soil moisture measurements by capacitance sensors in a drip-irrigated orchard," Sensors, vol. 20, no. 18, 2020.

[25] S. Evett, N. Agam, W. Kustas, P. Colaizzi, and R. Schwartz, "Soil profile method for soil thermal diffusivity, conductivity and heat flux: comparison to soil heat flux plates," Advances in Water Resources, vol. 50, pp. 41-54, 2012.

[26] G. Kargas and K. Soulis, "Performance analysis and calibration of a new low-cost capacitance soil moisture sensor," Journal of Irrigation and Drainage Engineering, vol. 138, no. 7, pp. 632641, 2012.

[27] M. Oates, A. Fernández-López, M. Ferrández-Villena, and A. Ruiz-Canales, "Temperature compensation in a low cost frequency domain (capacitance based) soil moisture sensor," Agricultural Water Management, vol. 183, pp. 86-93, 2017.

[28] H. Domsch and A. Giebel, "Estimation of soil textural features from soil electrical conductivity recorded using the EM38," Precision Agriculture, vol. 5, no. 4, pp. 389-409, 2004.

[29] J. Triantafilis and S. Lesch, "Mapping clay content variation using electromagnetic induction techniques," Computers and Electronics in Agriculture, vol. 46, no. 1-3, pp. 203-237, 2005.

[30] M. Mojid, D. Rose, and G. Wyseure, “A model incorporating the diffuse double layer to predict the electrical conductivity of bulk soil," European Journal of Soil Science, vol. 58, no. 3, pp. 560-572, 2007. 